\title{
The Lymnaeid genus Catascopia Meier-Brook et Bargues, 2002 (Mollusca: Gastropoda: Lymnaeidae), its synonymy and species composition
}

\begin{abstract}
M.V. Vinarski
Museum of Siberian Aquatic Molluscs, Omsk State Pedagogical University, 14 Tukhachevskogo Emb., Omsk, 644099, Russian Federation.

e-mail: radix.vinarski@gmail.com

ABSTRACT: The lymnaeid genus Catascopia Meier-Brook et Bargues, 2002 with the type species Limnaea catascopium Say, 1817 was emerged on the basis of molecular data exclusively. It contains at least four species distributed in the Holarctic region. However, as many as three generic names older than Catascopia are available for the designation of the lymnaeid clade including L. catascopium: Polyrhytis Meek, 1876, Ladislavella B. Dybowski, 1913, and Walterilymnaea Starobogatov et Budnikova, 1976. It is shown that the name Ladislavella should be used for this purpose rather than the oldest one, Polyrhytis, since the latter is based on the fossil species and it is impossible to establish the molecular affinity of its type species with recent lymnaeids. Two new synonymies are proposed: Catascopia $=$ Ladislavella syn.n. and Catascopia $=$ Walterilymnaea syn.n.). Morphologically, there are two distinct groups of species within Ladislavella: one includes species distributed in Northern Eurasia, and other contains species distributed in North America and the Asian part of the Beringia. The conchological and anatomical differences between these groups allow to consider them as two subgenera of Ladislavella: Ladislavella s.str. (type species Leptolimnaea terebra var. sorensis W. Dybowski, 1913 = Limnaea palustris var. terebra Westerlund, 1885), and Walterilymnaea (type species Limnaea catascopium Say, 1817).

How to cite this article: Vinarski M.V.2012. The Lymnaeid genus Catascopia Meier-Brook et Bargues, 2002 (Mollusca: Gastropoda: Lymnaeidae), its synonymy and species composition // Invert. Zool. Vol.9. No.2. P.91-104.
\end{abstract}

KEY WORDS: molecular taxonomy, synonymy, Lymnaeidae, Catascopia, Ladislavella, Polyrhytis.

\section{Род Catascopia Meier-Brook et Bargues, 2002 (Mollusca: Gastropoda: Lymnaeidae), его синонимия и видовой состав}

\section{М.В. Винарский}

Музейводныхмоллюсков Сибири при Омскомгосударственном педагогическом университете, наб. Тухачевского 14, Омск, 644099, Российская Федерация.

e-mail: radix.vinarski@gmail.com 
РЕЗЮМЕ: Род Catascopia Meier-Brook et Bargues, 2002 с типовым видом Limnaea catascopium Say, 1817 был установлен на основе исключительно молекулярных данных. Он включает не менее четырех видов, распространенных в Голарктике. Однако существует по меньшей мере три родовых названия, старших, чем Catascopia, которые пригодны для обозначения клады, включающей L. catascopium. Это Polyrhytis Meek, 1876, Ladislavella B. Dybowski, 1913 и Walterilymnaea Starobogatov et Budnikova, 1976. Показано, что название Ladislavella следует использовать для этой цели, тогда как более старое название Polyrhytis основано на ископаемом типовом виде, поэтому молекулярно-филогенетические отношения его с другими родами лимнеид не могут быть установлены. Предложены две новые синонимии: Catascopia = Ladislavella syn.n. и Catascopia = Walterilymnaea syn.n. На основе морфологии в составе Ladislavella выделяются две группы видов: первая включает виды, распространенные в северной части Евразии, вторая содержит виды, распространенные в Северной Америке и азиатской части Берингии. Конхологические и анатомические различия между ними позволяют рассматривать их в качестве подродов Ladislavella: Ladislavella s.str. (типовой вид Leptolimnaea terebra var. sorensis W. Dybowski, $1913=$ Limnaea palustris var. terebra Westerlund, 1885) и Walterilymnaea (типовой вид Limnaea catascopium Say, 1817).

как цитировать эту статью: Vinarski M.V. 2012. The Lymnaeid genus Catascopia MeirBrook et Bargues, 2002 (Mollusca: Gastropoda: Lymnaeidae), its synonymy and species composition // Invert. Zool. Vol.9. No.2. P.91-104.

КЛЮЧЕВЫЕ СЛОВА: молекулярная систематика, синонимия, Lymnaeidae, Catascopia, Ladislavella, Polyrhytis.

\section{Introduction}

Many years taxonomists employed macromorphological traits as the only tool for delineation of genera and subgenera within the family Lymnaeidae Rafinesque, 1815. Earlier workers used exclusively conchological characters for this purpose (see, for example, Mörch, 1864; Clessin, 1884; Westerlund, 1885a), however it is commonly accepted now that shell traits in lymnaeid snails are very variable and prone to modificating influence of different environmental factors (Hubendick, 1951; Walter, 1969; Arthur, 1982). In some cases, strong similarity of shell appearances between phylogenetically distant taxa may arise as a result of convergent processes (Patterson, Burch, 1978; Kruglov, Starobogatov, 1987). Some taxa, for instance, genus Aenigmomphiscola Kruglov et Starobogatov, 1981, lack a conchological diagnosis (Kruglov, 2008). Thus, conchological data alone are not sufficient for taxonomic purposes and usu- ally are of less significance as compared with the anatomical ones. Recent systems of the family are based on anatomical data predominantly though shell characters also are of use (Jackiewicz, 1998a; Kruglov, 2005).

A new way to arrange lymnaeid snails to higher taxa has been opened since the late 1990s, when new molecular techniques like DNA sequencing and some others were introduced into molluskan systematics (Remigio, Blair, 1997a, b; Bargues, Mas-Coma, 1997; Rybska et al., 2000; Remigio, 2002). Recently, a series of papers by Bargues et al. (2001, 2003, 2006; Bargues, Mas-Coma, 2005) has appeared, in which several molecular phylogenetic trees of Holarctic lymnaeids were presented. Though many species of this family are not yet sequenced, these trees are very helpful for testing of the earlier phylogenetic hypotheses based on the macromorphological characters (Starobogatov, 1976; Kruglov, Starobogatov, 1981; Jackiewicz, 1993, 1998a; Kruglov, 2005). Among 
the particular results of DNA sequencing studies carried out by Bargues and her collaborators, I would like to emphasize a striking case of polyphyly of the Holarctic lymnaeid (sub)genus Stagnicola Leach in Jeffreys, 1831. By means of the molecular techniques, Bargues et al. (2001, 2003, 2006; see also Remigio, 2002) revealed that this diverse taxon consists of as many as three separate clades, which may be treated as distinct monophyletic taxa of generic or subgeneric rank.

According to Bargues and her collaborators, one of these clades includes the type species of Stagnicola, Buccinum palustre O.F. Müller, $1774(\mathrm{M})^{1}$, and several related species, Stagnicola turricula (Held, 1836), S. corvus (Gmelin, 1791), and S. fusca (Pfeiffer, 1821). Hence, it should retain the name Stagnicola s.str. The second clade includes a Nearctic taxon Hinkleyia F.C. Baker, 1928 that previously was treated as a subgenus of Stagnicola (Burch, 1989), and the third one consists of four species: three Nearctic ones, S. catascopium (Say, 1817), S. elodes (Say, 1821), S. emarginata (Say, 1821), and a single Palaearctic species, S. occulta (Jackiewicz, 1959). The latter was described from Poland and since 1959 has been recorded from different countries of Northern, Central and Eastern Europe as well as from Siberia (Hudec, Brabenec, 1966; Stadnichenko, 1968; Jackiewicz, 1992, 1993, 1997, 1998b; Jackiewicz, von Proschwitz, 1991; Korniushin, 1999).

This third clade was earlier distinguished on the ground of macromorphological data by Walter (1969), who did not confer any taxonomic rank for it but designated it informally as 'advanced stagnicolines' distributed in North America. The clade is distinct from European 'primitive stagnicolines' grouping around $S$. palustris. Thus, 'advanced stagnicolines' have mainly Holarctic distribution, whereas 'primitive stagnicolines' form a Palearctic group of species (Walter, 1969).

Meier-Brook and Bargues (2002) have established a new lymnaeid genus Catascopia

${ }^{1}$ For a genus group names, the types species are indicated hereafter: $\mathrm{M}-$ by monotypy, OD - original designation
Meier-Brook et Bargues, 2002 with the type species Limnaea catascopium Say, 1817 (OD), for the sake of nomenclatorial formalization of the 'advanced stagnicolines'. This taxonomic decision became the first case of describing of a lymnaeid higher taxon on the basis of genetic data only. This genus has a strictly molecular diagnosis and can be distinguished from another stagnicoline taxa by "extraordinarily short lengths of the rDNA ITS-2 sequences which consist of 444-449 base pairs" (Meier-Brook, Bargues, 2002: 83), whereas rDNA ITS-2 lengths of all other European species of Stagnicola lie between 466 and 484 base pairs.

In my opinion, there are certain taxonomic and nomenclatorial problems concerning the species composition and synonymy of Catascopia and their discussion is the main goal of this article. I will argue that there is an older available name to designate 'advanced stagnicolines' in accordance with the International Code of Zoological Nomenclature (ICZN hereafter) rules.

\section{Material and methods}

The work is based on a critical analysis of relevant literature sources and on results of my own taxonomic work with Holarctic stagnicoline snails in rich malacological collections of the Zoological Institute of the Russian Academy of Sciences (Russia, Saint-Petersburg), Senckenberg Natural History Collections Dresden, Museum of Zoology (Germany, Dresden), and the Museum of Siberian Aquatic Mollusks (Russia, Omsk State Pedagogical University). These collections house a large amount of lymnaeid species from Eurasia and North America and I had an opportunity to examine all species placed within Catascopia by Meier-Brook and Bargues (2002), except of C. emarginata, as well as a range of closely related species such as Lymnaea atkaensis (Dall, 1884), L. liogyra (Westerlund, 1897), and L. terebra (Westerlund, 1885). I used the standard methods of investigations of Lymnaeidae described in detail by Hubendick (1951) Jackiewicz (1998a). These methods presuppose study of both con- 
chological and anatomical characters and include shell measurements, dissection of snails and investigation of the male copulatory organs.

Abbreviations for museum collections: ZIN - Zoological Institute RAS; SNSD Senckenberg Natural History Collections Dresden; MSAM - Museum of Siberian Aquatic Molluscs; GNH - Göteborgs Naturhistoriska Muséet (Sweden, Göteborg); USNM — United States National Museum (Washington, USA).

\section{Taxonomic rank of Catascopia}

There is no agreement among taxonomists on how many genera are there within the family Lymnaeidae, and two quite distinct approaches are discussed. The first one is that majority of lymnaeid species should be placed within a single diverse genus Lymnaea Lamarck, 1799 containing several subgenera (Kruglov, Starobogatov, 1993; Jackiewicz, 1998a; Kruglov, 2005). The point is that almost all lymnaeids are strikingly uniform in the overall structure (Bauplan) of their genitals in spite of clear differences in size and proportions of their shells (Hubendick, 1951; Walter, 1969; Kruglov, Starobogatov, 1981). In this case, only certain morphologically advanced groups are worthy of assigning them the rank of genus, for example, Omphiscola Rafinesque, 1819 (see Jackiewicz, 1998a), or Aenigmomphiscola Kruglov et Starobogatov, 1981 (see Kruglov, Starobogatov, 1981; Kruglov, 2008; Vinarski et al., 2011). Anatomical differences of lesser calibre, however, may be used for delineation of subgenera and sections within the genus Lymnaea (Kruglov, Starobogatov, 1993; Kruglov, 2008).

The opposite approach considers such commonly familiar subgenera as Lymnaea s.str., Galba Schrank, 1803, Radix Montfort, 1810, Stagnicola and so on as separate genera which can be distinguished by their conchological characters and ecological specificity (Baker, 1911; Zhadin, 1952; Burch, 1989; Ponder, Waterhouse, 1997; Glöer, 2002). In this case, the anatomical differences may also be taken in consideration, though in some instances there are virtually no qualitative differences between well established genera. For example, genital morphology in the genera Radix and Myxas Sowerby, 1822 is practically the same although these genera differ from each other both by conchological and molecular characters (Glöer, 2002; Pfenninger et al., 2006).

Catascopia is established within a taxonomic framework of the second type, therefore the generic rank was confidently ascribed to this taxon (Meier-Brook, Bargues, 2002). From the point of view of the alternative (two-genus) system, morphological differences between Catascopia and another stagnicolines are too slight to regard the former as a distinct genus. As another subgenera and genera of the family Lymnaeidae were defined by macromorphological, not genetical, characters, their direct comparison with Catascopia (based on molecular data solely) seems to be impossible (Vinarski, 2006). In some recent works it has been proposed even to treat this molecularly defined taxon as an incertae sedis group of species within Lymnaeidae which rank cannot be established exactly (Khokhutkin et al., 2009; Andreyeva et al., 2010). However, this "molecular origin" of Catascopia does not preclude us to seek for its proper place in the system following the ICZN rules.

\section{What is the proper generic name for 'advanced stagnicolines'?}

The 'advanced stagnicolines' sensu Walter (1969) includes a series of species that are characterized by anatomical traits exclusively. This author himself placed only Lymnaea catascopia (and its closest relatives from Nearctic) and L. occulta there. According to Meier-Brook and Bargues (2002), this group forms a distinct phylogenetic lineage and includes four species previously classified within Stagnicola: S. catascopia, S. elodes, S. emarginata, and S. occulta (see above). Later, Vinarski (2003) suggested that recent findings of the species L. occulta in Siberia described by Jackiewicz (1992, 1998b) should be attributed to a Siberian stagnicoline 
species L. terebra. A special study of conchological and anatomical traits of $L$. occulta and $L$. terebra with examination of the type materials of the both species revealed that Galba occulta Jackiewicz, 1959 is a junior synonym of Limnaea palustris var. terebra Westerlund, 1885 (Vinarski, Glöer, 2008). Thus, Vinarski and Glöer (2008) proposed to include the latter species in the genus Catascopia. This proposition has been corroborated by means of DNA sequencing of Siberian specimens of $L$. terebra that are virtually identical with $L$. occulta from Poland (Vinarski et al., 2012).

Obviously, Catascopia is not the oldest available name to designate a stagnicoline lineage including L. catascopia and related species listed above. More than 35 years ago, Starobogatov and Budnikova (1976) established a new lymnaeid subgenus, Lymnaea (Walterilymnaea), with $L$. catascopia as its type species (OD). Unfortunately, this generic name was overlooked by Meier-Brook and Bargues (2002) when they described a new lymnaeid genus with $L$. catascopia as its type species. Thus, Catascopia is a junior objective synonym of Walterilymnaea Starobogatov et Budnikova, 1976.

Later, Kruglov and Starobogatov (1989) placed L. catascopium and L. emarginata in the subgenus Polyrhytis Meek, 1876, which is distributed in the extreme north-east of Russia, North America and Hawaii. Consequently, Walterilymnaea has been regarded as a junior synonym of Polyrhytis (Kruglov, Starobogatov, 1989), or Stagnicola (Ponder, Waterhouse, 1997), and Polyrhytis may be considered as the oldest available name to substitute Catascopia.

However, there are strong objections against using the generic name Polyrhytis for the naming of 'advanced stagnicolines' (= Stagnicola catascopia group). First of all, none of recent stagnicoline species corresponds completely to the diagnosis of this genus presented by its author (Meek, 1876): "much like the last $[R a$ $d i x]$ in form but bearing distinct, regular, vertical costae" as well as to the expanded conchological diagnosis presented by Baker: "shell with well-marked longitudinal folds or ribs; spire broadly acute, generally shorter than aperture; axis twisted; columella lip broadly expanded, obscuring the fold more or less; umbilical chink well marked". For example, shell characters of $S$. occulta, described in detail by Jackiewicz (1959), have nothing to do with such diagnosis. The presence of well-marked and regular axial costae on the shell surface is a characteristic trait of Limnaea kingi Meek, 1876, a fossil lymnaeid from Neogene deposits of North America that is the type species of the (sub-) genus Polyrhytis (M). This trait is unique among lymnaeids, and this fact led Meek (1876: 532 ) to separate $L$. kingi in a special subgenus. The only extant species considered to be allied to L. kingi is Lymnaea utahensis (Call, 1884), initially described as a variety of L. ampla (see Baker, 1911; Hubendick, 1951). It is an endemic species of Utah (USA) and its internal structure is still not known; moreover, this species is, most probably, extinct now as living specimens have not been registered since the 1930s (Oliver, Bosworth, 1999). Baker (1911) assumed that L. utahensis is a descendent of $L$. kingi but relations of the two species to $L$. catascopium and allied taxa are rather unclear. Hubendick (1951) could not determine the taxonomic position of L. utahensis within the system of Lymnaeidae. I wish to add that most of $L$. utahensis specimens illustrated by Baker (1911, pl. XXII, fig. 9-11, pl. XXIV, fig. 22-27) have Radixshaped shells not similar to a typical for Stagnicola shape, and both Meek (1876) and Dall (1905: 65) described Polyrhytis as Radix-like lymnaeids bearing axial costae or ribs on the shell surface.

The nature of this peculiar surface sculpture is not known exactly. Some authors suggested that it arises as a consequence of unfavorable conditions of life, in particular, as a result of increased salinity in waterbodies where L. utahensis lives (Berg, 1922). Clearly, if this trait is of an ecophenotypical origin, its taxonomic value becomes negligible.

Despite the facts above, some recent authors (Burch, Tottenham, 1980; Burch, 1989; Oliver, Bosworth, 1999) place L. utahensis putatively in the (sub)genus Stagnicola. Moreover, Burch 
and Tottenham (1980) include this species to the Stagnicola emarginata/catascopium group, and the species $S$. bonnevillensis (Call, 1884) that is belonging to this group as well, is sometimes considering as a junior synonym of $L$. kingi (D. Campbell, personal communication). The affiliation of $S$. bonnevillensis with the 'advanced stagnicolines' was revealed by means of DNA sequencing by Remigio (2002). These facts seem to present a good reason for regarding Polyrhytis as a senior synonym of Catascopia. Molecular techniques (as well as anatomical data) are not suitable for fossil organisms, hence, any decisions on true taxonomic position of $L$. king $i$ will be of necessity disputable. That's why I refrain here from acclaiming Polyrhytis to be a senior synonym of Catascopia (though this possibility cannot be refuted completely).

The last taxonomic name is needed to discuss here is Ladislavella B. Dybowski, 1913 with the type species Leptolimnaea terebra var. sorensis W. Dybowski, 1913 (OD). Kozhov (1936: 129) mentioned that there are no differences between var. sorensis and typical Lymnaea terebra from Siberia. I had an opportunity to check this synonymy by examination of the type series of L. terebra var. sorensis kept in the ZIN collection. Kruglov and Starobogatov (1986, 1993) treated Leptolymnaea sorensis as a junior synonym of Fossaria lindholmi W. Dybowski, 1913 and used Ladislavella as a name for designation of a section within the subgenus Stagnicola including Lymnaea terebra, L. liogyra, and L. vulnerata (Küster, 1862) sensu Kruglov and Starobogatov, 1986 non Jackiewicz, 1988 (=L. occulta). The conspecifity of L. palustris var. terebra and F. lindholmi was established by Kozhov (1936: 130) and confirmed by Vinarski and Andreyev (2003).

In order to make this complicated taxonomic story more clear I give a detailed synonymy of Lymnaea terebra below along with a table (Table 1) that demonstrates views of different taxonomists on the subgeneric structure of Stagnicola s.lat.

The range of junior synonyms of Limnaea palustris var. terebra includes as many as 10 taxa:
- Limnaea palustris var. terebra Westerlund, 1885b: 155.

- Fossaria kultukiana B. Dybowski, 1913: 187, Taf. IV, fig. 17.

-F. lindholmi W. Dybowski, 1913: 130, Taf. II, fig. 7 a-i.

-F. pulchelletta B. Dybowski, 1913: 189, Taf. IV, fig. 19.

- Galba occulta Jackiewicz, 1959: 39, tabl. III, XXIV-XXV.

- Ladislavella terebra var. pulla B. Dybowski, 1913: 180, Taf. IV, fig. 13.

- L. terebra var. sorica B. Dybowski, 1913: 183, Taf. IV, fig. 14.

- Leptolimnaea liogyra var. sorensis W. Dybowski, 1913: 130.

- L. terebra var. sorensis W. Dybowski, 1913: 130.

- L. terebra var. sorensiana W. Dybowski, 1913: 130.

- Lymnaea palustris bolotensis Mozley, 1934: 5, pl. 1, fig. 3 (see Andreyeva et al., 2010 for explanation).

I managed to study the type materials (syntypes, lectotypes, or neotypes) of all of these nominal taxa (except of $F$. kultukiana and $L$. liogyra var. sorensis; it is not known where the type series are kept now). The shells from these type series are pictured in Fig. 1. It should be noted that the names Leptolimnaea liogyra var. sorensis and L. terebra var. sorensis are secondary homonyms, and, in the absence of the first reviser, this homonymy should be resolved here. Since the both names were described on the same page of W. Dybowski (1913) paper, there is no possibility to establish their priority objectively. In this situation I select Leptolimnaea terebra var. sorensis to have priority before $L$. liogyra var. sorensis. The latter must be considered as a junior secondary homonym.

Thus, I consider Ladislavella (with the type species Leptolimnaea terebra var. sorensis W. Dybowski, $1913=$ Lymnaea palustris var. terebra Westerlund, 1885) to be the oldest available name for designation of the 'advanced stagnicoline' clade. Three new generic synonymies are proposed (Catascopia $=$ Walterilymnaea syn.n.; Catascopia = Ladislavella syn.n.; Wal- 


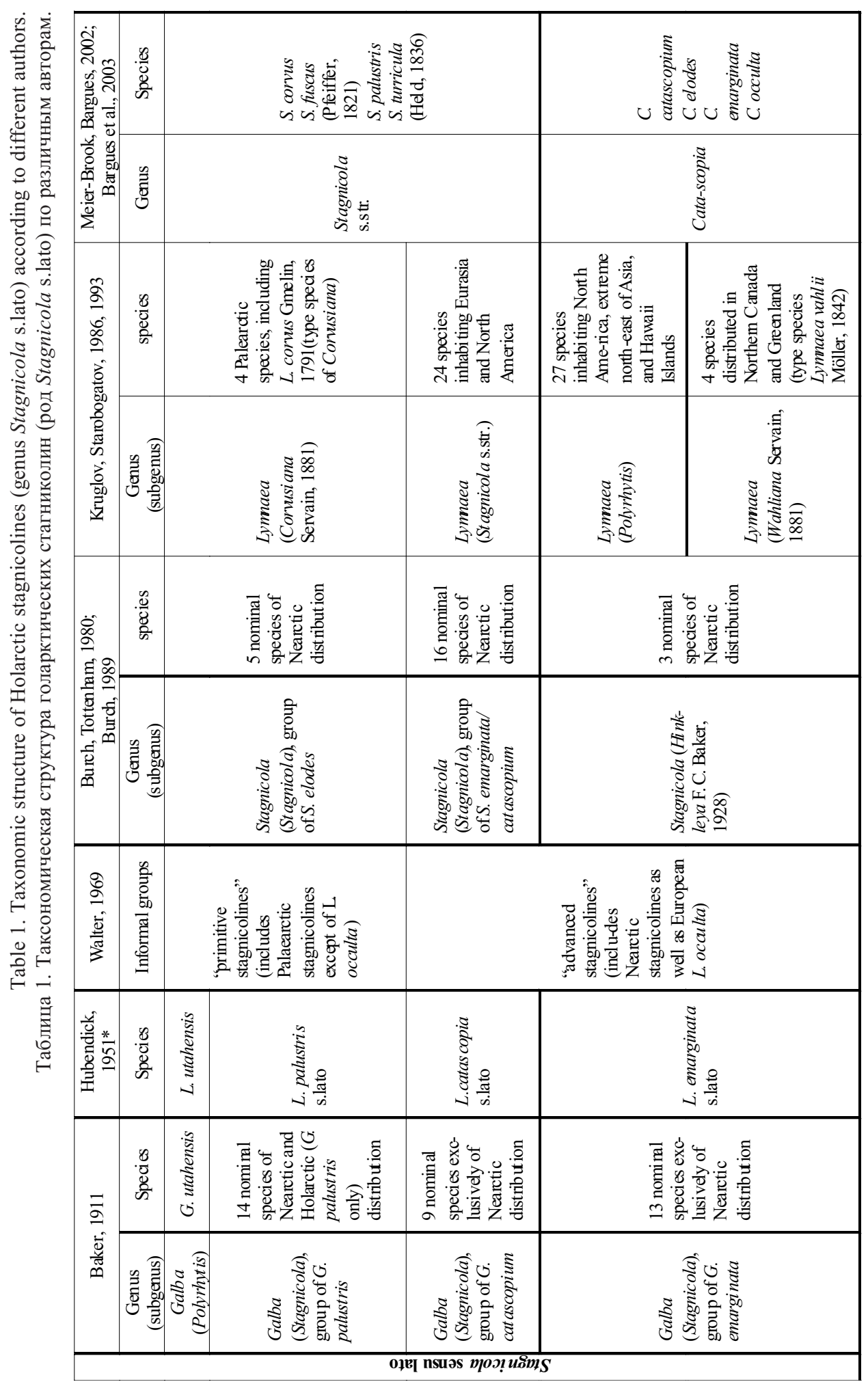

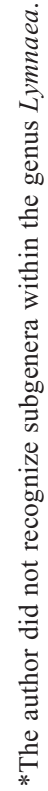




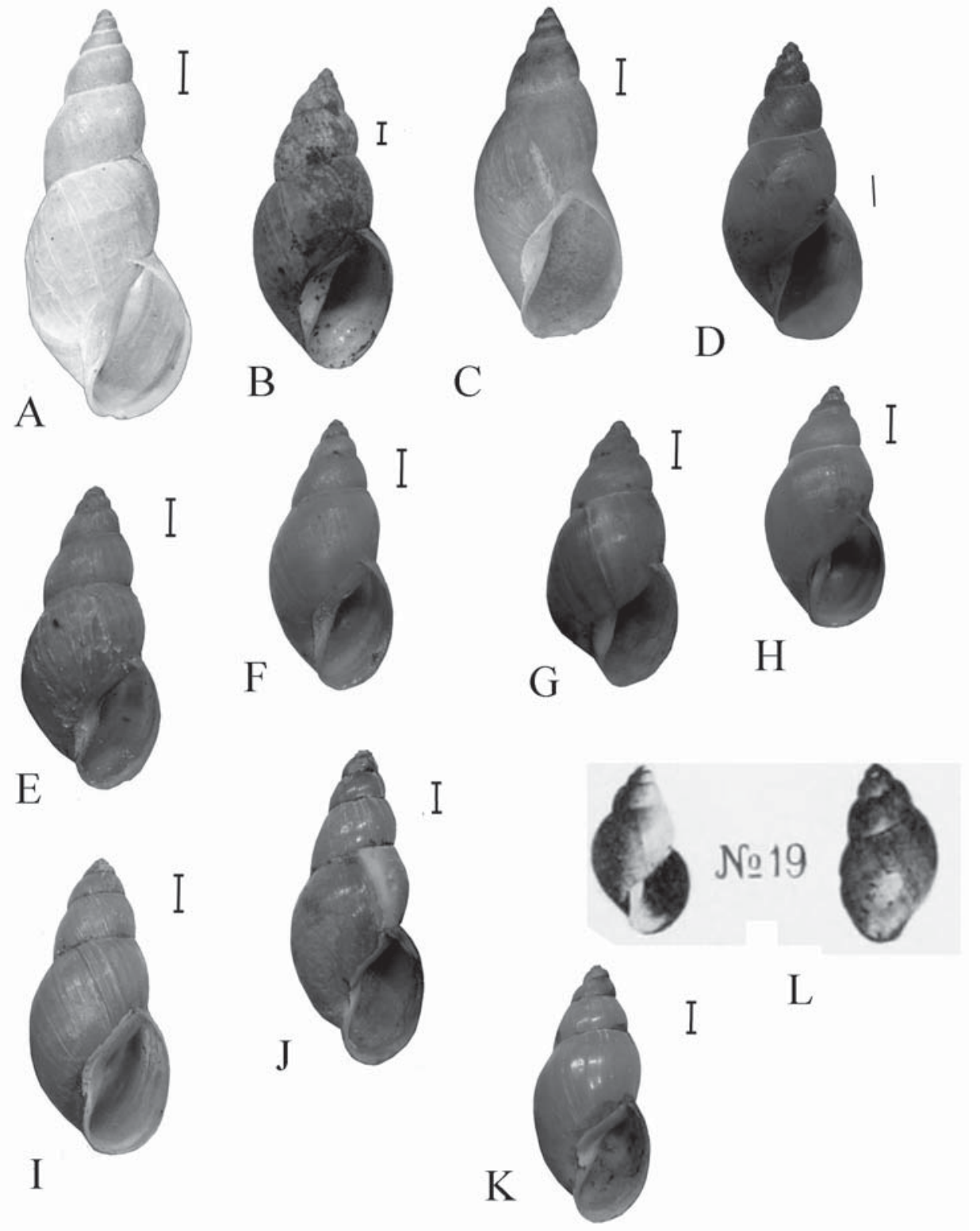

Fig. 1. Shells type specimens of Limnaea palustris var. terebra and its assumed synonyms.

A - The neotype of L. palustris var. terebra (GNM; see Vinarski, Glöer, 2008 for details); B - Galba occulta (paratype, ZIN); C — Lymnaea palustris bolotensis (syntype, USNM 469821); D — Fossaria lindholmi (paralectotype, ZIN); EF - Leptolymnaea terebra var. sorensiana (syntypes, ZIN); G-H — Ladislavella terebra var. pulla (syntypes, ZIN); I - Leptolymnaea terebra var. sorensis (syntype, ZIN); J-K - Ladislavella terebra var. sorica (syntypes, ZIN); L F. pulchelletta (after B. Dybowski, 1913). Scale bars $2 \mathrm{~mm}$.

Рис. 1. Раковины из типовых серий Limnaea palustris var. terebra и его предполагаемых синонимов. A — неотип L. palustris var. terebra (GNM; см. Vinarski, Glöer, 2008); B — Galba occulta (паратип, ZIN); C Lymnaea palustris bolotensis (синтип, USNM 469821); D - Fossaria lindholmi (паралектотип, ZIN); E-F Leptolymnaea terebra var. sorensiana (синтипы, ZIN); G-H — Ladislavella terebra var. pulla (синтипы, ZIN); I Leptolymnaea terebra var. sorensis (синтип, ZIN); J-K — Ladislavella terebra var. sorica (синтип, ZIN); L - F. pulchelletta (из: В. Dybowski, 1913). Масштаб 2 мм. 
terilymnaea $=$ Ladislavella syn.n.). Is Ladislavella of generic or subgeneric rank depends on which taxonomic methodology is chosen by a particular malacologist. From the cladistic point of view, most monophyletic groups within Lymnaeidae should be ranked as genera, whereas proponents of the alternative approach, based on the 'evolutionary' systematics, would recognize Ladislavella as merely a subgenus within the genus Lymnaea s. lato (see Vinarski et al., 2011 for details).

\section{On species composition and taxo- nomic structure of Ladislavella}

Kruglov and Starobogatov (1986, 1993) listed three Palearctic species of lymnaeid snails belonging to their section Ladislavella (see above). No Nearctic taxa were included there. In my opinion, this taxon is of Holarctic distribution. It is remarkable that Nearctic and Palaearctic species of Ladislavella show prominent differences in their morphology, including differences in some taxonomically important traits. These differences are listed below.

1.Eurasian species of Ladislavella have a similar shape of shell with relatively high spire and small aperture (see Fig. 1). This shell shape is characteristic also for Buccinum palustris the type species of Stagnicola (Falkner, 1984). North American representatives of Ladislavella are typically possessing the same Stagnicolashaped shell (see, for example, Fig. 2, c), but some species may demonstrate a quite another shell appearance resembling that of Radix species. It is characterized by depressed spire, very large body whorl and enlarged aperture. Such a shape is observed in so called "lake form" of $L$. catascopia (see Fig. 2, e, f). Radix-shaped shells have never been recorded in representatives of Ladislavella from Palaearctic region.

2.Walter (1969) states that L. catascopia and L. elodes have the "penial knot" on the penis which this author regards to be very characteristic for 'advanced stagnicolines'. This trait is found among other groups of Lymnaeidae that sometimes is considered as being the most primitive living representatives of the family (Star- obogatov, 1976; Kruglov, 2005). For example, the penial knot is registered in Lymnaea stagnalis (L., 1758), L. corvus (Gmelin, 1791), L. kazakensis Mozley, 1934 and some other species (Jackiewicz, 1998a; Kruglov, 2005). The Beringian species of Ladislavella such as $L$. atkaensis have this trait as well (Kruglov, Starobogatov, 1989). On the other hand, all species of the Eurasian branch of Ladislavella lack this character (Kruglov, Starobogatov, 1986).

3.The copulatory apparatus of Nearctic species of advanced stagnicolines is visibly different in its shape and proportions from that of Eurasian snails (Fig. 3). In particular, in Eurasian L. terebra the penis sheath and the praeputium are of approximately the same width and length; the penis sheath is oblong with relatively small bulbous bulge on its distal end (Fig. 3, a). In Nearctic species, such as L. elodes (see Fig. 3, b) and L. atkaensis (see Kruglov, Starobogatov, 1989), the penis sheath is short and strongly inflated. Some authors (e.g. Kruglov, 2005) regard such degree of difference in the morphology of the copulatory organ as a character of at least subgeneric rank.

These differences reflect relatively profound intrageneric divergence between Palaearctic and Nearctic branches of Ladislavella that, most probably, is the result of a long spatial isolaton. In my opinion, Ladislavella species of North America and the Asian part of Beringia merit to be combined in a distinct subgenus. In this case, it must retain taxonomic name Walterilymnaea as the oldest available name for designating the L. catascopia group. The taxonomic structure of Ladislavella proposed here is as follows:

1. Ladislavella (subgenus Ladislavella s.str.). Diagnosis: shell slender, cylindric or high-turriculate. Penis sheath relatively long and narrow and its length is comparable with the length of the praeputium. Penial knot is absent. Distribution: Eurasia (Eastern Europe, Siberia, southern part of the Russian Far East). Includes at least two species: L. liogyra and L. terebra.

2. Ladislavella (subgenus Walterilymnaea Starobogatov et Budnikova, 1976). Diagnosis: shell relatively wide, high-conical to almost earshaped (Radix-like). Penis sheath short and in- 


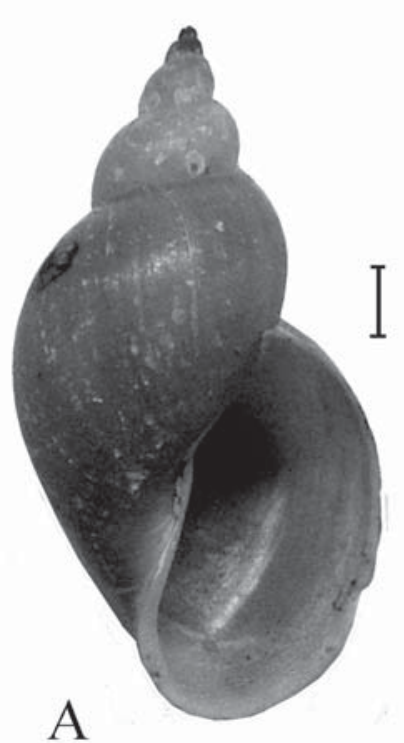

B

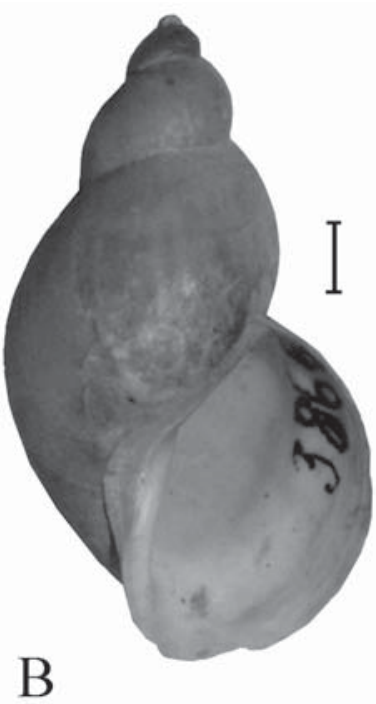

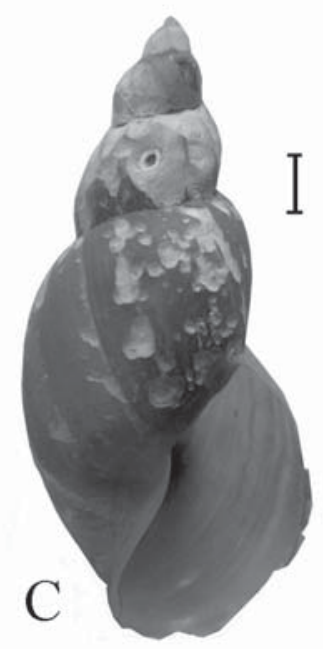

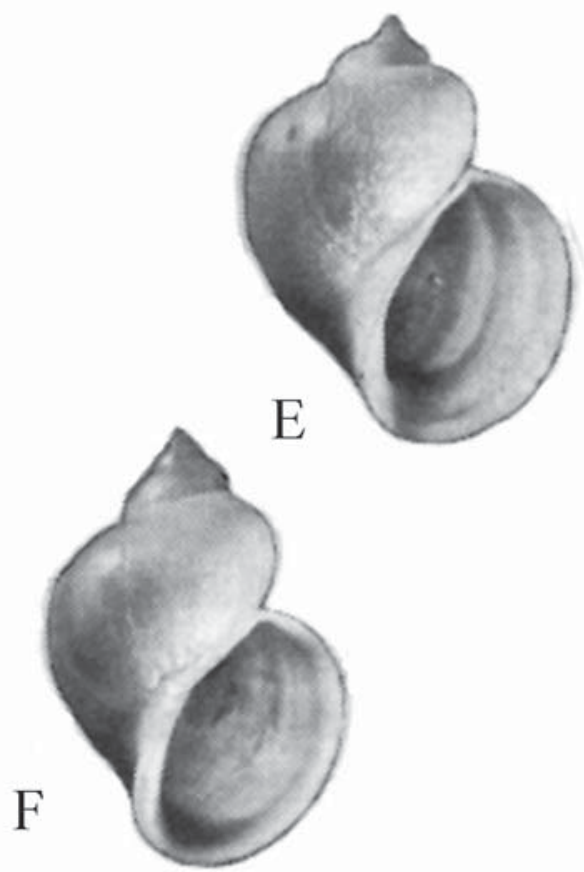

Fig. 2. Shells of the species belonging to the Nearctic branch of Ladislavella.

A - L. catascopia (Black Lake, Michigan, USA; ZIN 1); B - L. catascopia (Delaware, USA; SNSD 3868); C - L. elodes (Ann Arbor, Michigan, USA; MSAM 15-1755); D — L. atkaensis (Chukchi Peninsula, Russia; ZIN); E-F "lake form" of L. catascopia (after Walter, 1969). Scale bars $2 \mathrm{~mm}$.

Рис. 2. Раковины видов, принадлежащих неарктической ветви Ladislavella.

A - L. catascopia (Black Lake, Мичиган, CША; ZIN); B - L. catascopia (Delaware, CШA; SNSD 3868); C - L. elodes (Ann Arbor, Мичиган, CША; MSAM 15-1755); D - L. atkaensis (п-ов Чукотка, Россия; ZIN); E-F “озерная форма” L. catascopia (из: Walter, 1969). Масштаб 2 мм. 


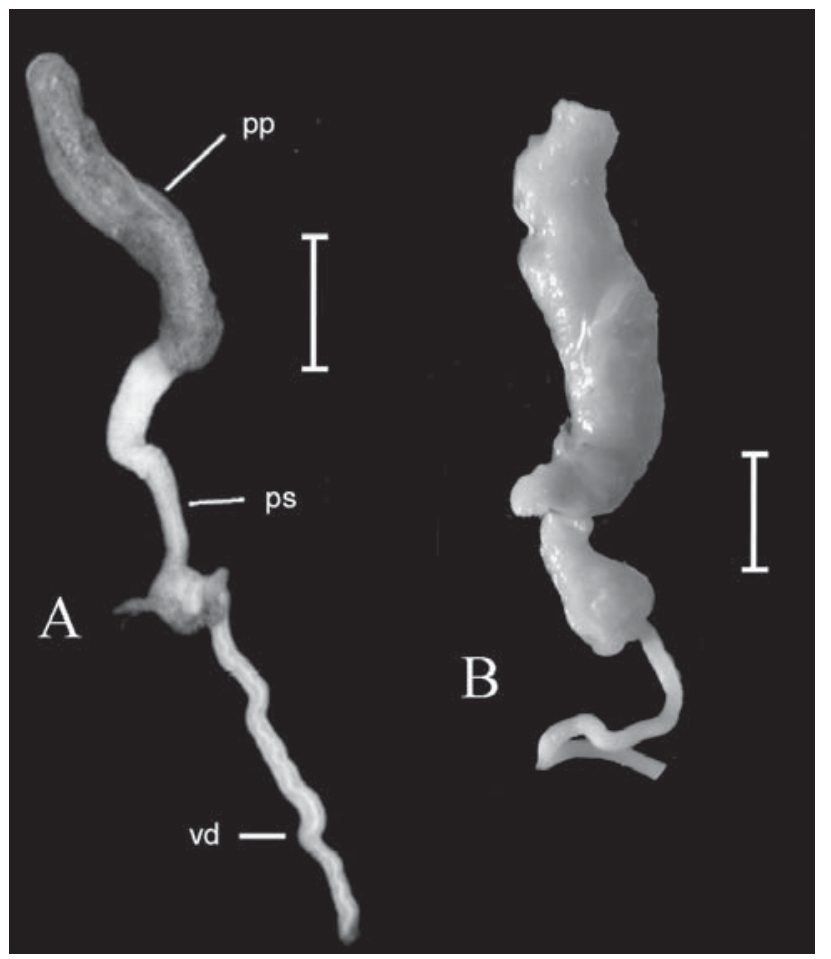

Fig. 3. Copulatory apparatuses of Ladislavella species.

A - L. terebra (after Vinarski and Glöer, 2008); B - L. elodes (Ann Arbor, Michigan, USA). Scale bars $1 \mathrm{~mm}$. Abbreviations: pp praeputium, ps - penis sheath, vd — vas deferens.

Рис. 3. Копулятивные аппараты видов рода Ladislavella.

А - L. terebra (из: Vinarski, Glöer, 2008); B - L. elodes (Ann Arbor, Мичиган. США). Масштаб 1 мм. Обозначения: pp - препуциум, ps - мешок пениса, vd - семяпровод.

flated, shorter than praeputium. Penial knot is present. Distribution: North America, Asian part of Beringia (extreme north-east of Russia). This taxon includes two group of species that are discussed below.

A. North American group. It includes at least three Nearctic species listed by MeierBrook and Bargues (2002) within Catascopia as well as Stagnicola bonnevillensis (see Remigio, 2002). All the species are distributed in USA and Canada (Burch, Tottenham, 1980; Clarke, 1981; Burch, 1989). According to the North American authors (Baker, 1911; Burch, 1989), there are much more stagnicoline species in Nearctic fresh waterbodies that are closely related to the four species above and form Stagnicola elodes group and Stagnicola emarginata/catascopium group. Burch (1989) places 21 species into these two groups. Their taxonomic position should be clarified in future by means of molecular tools.

B. Beringian group. The territory of Beringia covers Alaska and the Yukon Territory in
North America and areas of the extreme NorthEast Asia in Russia. From the malacogeographic point of view, Beringia represents a separate area inhabited by many species of freshwater mollusks having the American-Asian distribution(Prozorova, Foster, 1997; Prozorova, 1998). It is dwelled by a range of stagnicoline species that are placed to Polyrhytis by Russian authors (Kruglov, Starobogatov, 1989, 1993; Prozorova, 1998; Kruglov, 2005). The most studied of these taxa is L. atkaensis, or frigid pond snail, that is widely distributed in the tundra zone of Alaska and adjacent areas (Clarke, 1981; Maciolek, 1989) and in the waterbodies of the Chukchi Peninsula (Kruglov, 2005). It is known from the Alaska Holocene deposits as well (Oswald, 2006). Kruglov (2005) places 6 species to this Beringian group, however none of them is investigated by means of molecular techniques.

Possibly, the genus Ladislavella has an $\mathrm{Ne}-$ arctic origin, but further study is needed to resolve its origine as well as species composition. 


\section{Acknowledgements}

I thank Dr. David Campbell (University of Alabama, Tuscaloosa, USA) for discussing some points of the article and information about identity of 'Stagnicola' bonnevillensis from North America. I acknowledge Peter Glöer (Hetlingen, Germany) for longstanding discussions on lymnaeid taxonomy and sending me specimens of Stagnicola elodes for the anatomical study. Prof. Dr. Santiago Mas-Coma (University of Valencia, Spain) is acknowledged for sending me reprints of his papers on molecular taxonomy of Lymnaeidae. I am grateful to Dr. Yuri Kantor (Severtsov's Institute of Ecology and Evolution, Moscow, Russia), who kindly provided me with photos of the $L$. palustris bolotensis syntype. I thank Dr. Pavel Kiyashko and Mrs. Lidyia Yarochnovich (ZIN, Saint-Petersburg, Russia) and Dipl.-Biol. Katrin Schniebs (SNSD, Dresden, Germany) for their kind help during my work with the museum collections. Remarks of two referees led to significant improvement of the text. Financial support for this study was obtained from the Russian Fund for Basic Research (grant\# 12-04-98056-r_sibir_a) and Russian Ministry of Education and Science (project \# 4.2326.2011).

\section{References}

Andreyeva S.I., Andreyev N.I., Vinarski M.V. 2010. [Key to freshwater gastropods of Western Siberia (Mollusca: Gastropoda). Vol.1. Gastropoda: Pulmonata. Fasc. 1. Families Acroloxidae and Lymnaeidae]. Omsk: The authors. 200 pp. [in Russian].

Arthur W. 1982. Control of shell shape in Lymnaea stagnalis // Heredity. Vol.49. P.153-161.

Baker F.C. 1911. The Lymnaeidae of North and Middle America // Special publication of the Chicago Academy of Sciences. Vol.3. XVI+539 p.

Bargues M.D., Mas-Coma S. 1997. Phylogenetic analysis of lymnaeid snails based on 18S rDNA sequences // Molecular Biology and Evolution. Vol.14. No.5. P.569-577.

Bargues M.D., Mas-Coma S. 2005. Reviewing lymnaeid vectors of fascioliasis by ribosomal DNA sequence analyses // Journal of Helminthology. Vol.79. P.257267.

Bargues M.D., Artigas P., Jackiewicz M., Pointier J.P., Mas-Coma S. 2006. Ribosomal DNA ITS-1 sequence analysis of European stagnicoline Lymnaeidae (Gastropoda) // Heldia. Bd.6. No.1-2. P.57-68.

Berg L.S. 1922. [Nomogenesis, or Evolution determined by Law] // Trudy Geograficheskogo Instituta. T.1. P.1-320 [in Russian].

Bargues M.D., Horák P., Patzner R.A., Pointier J.P., Jackiewicz M., Meier-Brook C., Mas-Coma S. 2003. Insights into relationships of Palearctic and Nearctic lymnaeids (Mollusca: Gastropoda) by rDNA ITS-2 sequencing and phylogeny of stagnicoline intermediate host species of Fasciola hepatica // Parasite. Vol.10. P.243-255.

Bargues M. D., Vigo M., Horák P., Dvorak J., Patzner R. A., Pointier J. P., Jackiewicz M., Meier-Brook C., Mas-Coma S. 2001. European Lymnaeidae (Mollusca: Gastropoda), intermediate hosts of trematodiases, based on nuclear ribosomal DNA ITS-2 sequences // Infection, Genetics and Evolution. Vol.1. P.87-107.

Burch J.B. 1989. North American freshwater snails. Hamburg (Michigan): Malacological publications, $365 \mathrm{p}$.

Burch J.B., Tottenham J. 1980. North American freshwater snails: species list, ranges and illustrations // Walkerana. Vol.1. P.1-215.

Clarke H.A. 1981. The Freshwater Molluscs of Canada. Ottawa: National Museum of Natural Sciences. $446 \mathrm{p}$.

Clessin S. 1884. Deutsche-Exkurskion-Mollusken-Fauna. Nurnberg: Bauer et Raspe. $663 \mathrm{~S}$.

Dall W.D. 1905. Land and fresh water mollusks of Alaska and adjoining regions // Harriman Alaska Series. New York: Doubleday, Page \& Co. Vol.13. P.1-171.

Dybowski B. 1913. Bemerkungen und Zusatze zu der Arbeit von Dr. W. Dybowski "Mollusken der Uferregion des Baikalsees.” // Ezhegodnik Zoologicheskogo Muzeya Imperatorskoi Akademii Nauk. Bd.17 (for 1912). S.165-218.

Dybowski W. 1913. Mollusken aus der Uferregion des Baikalsees // Ezhegodnik Zoologicheskogo Muzeya Imperatorskoi Akademii Nauk. Bd 17 (for 1912). S.123-143.

Falkner G. 1984. Stagnicola palustris (O.F. Müller, 1774) von Originalfundort (Basommatophora, Lymnaeidae) // Heldia. Bd.1. No.1. S.15-21.

Glöer P. 2002. Die Sußwassergastropoden Nord- und Mitteleuropas: Bestimmungschlussel, Lebenweise, Verbreitung // Die Tierwelt Deutschlands. Hackenheim: Conchbooks. Bd.73. S.1-327.

Hubendick B. 1951. Recent Lymnaeidae. Their variation, morphology, taxonomy, nomenclature and distribution // Kungliga Svenska Vetenskaps-akademiens Handlingar. Fjärde Serien. Bd.3(1). P.1-223.

Hudec V., Brabenec J. 1966. Neue Erkenntnisse über die Schnecken der Gesamtart Galba palustris (Müll.) aus der Tschechoslowakei // Folia Parasitologica. Bd.13. S.132-143.

Jackiewicz M. 1959. Badania nad zmiennoscia i stanowiskiem systematycznym Galba palustris O.F. Müll. // Prace komissii biologicznej, wydzia ${ }^{3}$ matematicznoprzyrodniczy. Poznaske towarzystwo przyjaciol nauk. Vol.19. P.1-86. 
Jackiewicz M. 1988. Anatomy and taxonomic status of Lymnaea vulnerata (Kuster, 1862) (Mollusca, Gastropoda) // Bulletin de la Société des amis des sciences et des lettres de Poznań. Serie D. Vol.26. P.125-128.

Jackiewicz M. 1992. Lymnaea (Stagnicola) occulta (Jackiewicz, 1959) (Gastropoda: Pulmonata) in Sibirien // Mitteilungen der Deutsche Malacozoologische Gesellschaft. Bd.49. S.13-16.

Jackiewicz M. 1993. Phylogeny and relationships within European species of the family Lymnaeidae (Gastropoda: Pulmonata: Basommatophora) // Folia Malacologica. Vol.5. P.61-96.

Jackiewicz M. 1997. New European locality of Lymnaea (Stagnicola) occulta (Jackiewicz, 1959) (Gastropoda, Basommatophora, Lymnaeidae)// Malakologische Abhandlungen, Museum für Tierkunde Dresden. Bd.18. P.255-259.

Jackiewicz M. 1998a. European species of the family Lymnaeidae (Gastropoda Pulmonata Basommatophora) // Genus. Vol.9. P.1-93.

Jackiewicz M. 1998b. Lymnaea (Stagnicola) occulta (Jackiewicz, 1959) in the Selenga River delta at the Baikal Lake (Siberia) (Gastropoda, Basommatophora, Lymnaeidae) // Malakologische Abhandlungen, Museum für Tierkunde Dresden. Vol.19. P.53-57.

Jackiewicz M., von Proschwitz T. 1991. Lymnaea (Stagnicola) occulta (Jack.), Lymnaea (Lymnaea) vulnerata Küst. und Lymnaea (Lymnaea) corvus (Gmel.) drei für Schweden neue Schlammschneckenarten (Gastropoda, Basommatophora: Lymnaeidae) // Malakologische Abhandlungen, Museum für Tierkunde Dresden. Bd.15. S.125-132.

Khokhutkin I.M., Vinarski M.V., Grebennikov M.E. 2009. [Molluscs of the Urals and the adjacent areas. The family Lymnaeidae (Gastropoda, Pulmonata, Lymnaeiformes). Fasc. 1.] Yekaterinburg: Goshchitskiy Publishers. 156 p. [in Russian].

Korniushin A.V. 1999. New records of Lymnaea (Stagnicola) species in the West Ukraine (Gastropoda: Basommatophora: Lymnaeidae) // Malakologische Abhandlungen, Museum für Tierkunde Dresden. Bd.19. S.281-286.

Kozhov M.M. 1936. [Molluscs of Baikal Lake. Taxonomy, distribution, ecology, some data on genesis and history] // Trudy Baikal'skoi Limnologicheskoi Stantsii. Vol.8. P.1-320 [in Russian].

Kruglov N.D. 2005. [Molluscs of the family Lymnaeidae (Gastropoda Pulmonata) of Europe and Northern Asia]. Smolensk: SGPU Publishing. 507 p. [in Russian].

Kruglov N.D. 2008. [Two systems of the molluscs of the family Lymnaeidae (Gastropoda, Pulmonata): European and Russian. Where the truth is? Part 1. The analysis of the system at generic and subgeneric levels] // Izvestija Smolenskogo Gosudarstvennogo Universiteta. Vol.2. P.33-51 [in Russian].

Kruglov N.D., Starobogatov Ya.I. 1981. [A new genus of the Lymnaeidae and taxonomy of the subgenus $\mathrm{Om}$ phiscola (Lymnaea) (Pulmonata, Gastropoda)] // Zoologicheskiy Zhurnal. Vol.60. No.7. P.965-977 [in Russian].
Kruglov N.D., Starobogatov Ya.I. 1986. [Molluscs of the subgenus Stagnicola of the genus Lymnaea of the USSR fauna] // Byulleten' Moskovskogo obschchestva ispytatelej prirody. Serija biologicheskaja. Vol.91. No.2. P.59-72 [in Russian].

Kruglov N.D., Starobogatov Ya.I. 1987. [Life-forms of Lymnaeidae and some problems of the construction of system] // Mollyuski: Rezultaty i perspektivy ikh issledovanij. Leningrad: Nauka Publ. Vol.8. P.68-70 [in Russian].

Kruglov N.D., Starobogatov Ya.I. 1989. [Molluscs of the subgenus Polyrhytis of the genus Lymnaea of the fauna of the USSR (Pulmonata, Lymnaeidae)] // Zoologicheskij Zhurnal. Vol.68. No.3. P.14-20 [in Russian].

Kruglov N.D., Starobogatov Ya.I. 1993. Annotated and illustrated catalogue of species of the family Lymnaeidae (Gastropoda Pulmonata Lymnaeiformes) of Palaearctic and adjacent river drainage areas. Part $1 / /$ Ruthenica. Vol.3. No.1. P.65-91.

Maciolek J.A. 1989. Tundra ponds of the Yukon Delta, Alaska, and their macroinvertebrate communities // Hydrobiology. Vol.172. P.193-206.

Meek F.B. 1876. A Report on the Invertebrate Cretaceous and Tertiary Fossils of the Upper Missouri Country // Report of the Unuted States Geological Survey of the territories. Vol.9. xiv $+629 \mathrm{p}$.

Meier-Brook C., Bargues M.D. 2002. Catascopia, a new genus for three nearctic and one palaearctic stagnicoline species (Gastropoda: Lymnaeidae) // Folia Malacologica. Vol.10. No.2. P.83-84.

Mozley A. 1934. New fresh-water mollusks from northern Asia// Smithsonian Miscellaneous Collections. Vol.92. No.2. P.1-7.

Mörch O.A. 1864. Synopsis Molluscorum terrestrium et fluviatilium Daniae. Kjöbenhavn. 105 S.

Oliver G.V., Bosworth W.R. III. 1999. Rare, imperiled and recently extinct or extirpated mollusks of Utah: A literature review. Utah Conservation Data Center. [cited 13.10.2011] Available from: http://dwrcdc. nr.utah.gov/ucde/ViewReports/mollrpt.htm

Oswald W.W. 2006. Mollusks in a Holocene lake-sediment core from the Arctic Foothills of northern Alaska // The Nautilus. Vol.120. No.1. P.30-33.

Patterson C.M., Burch J.B. 1978. Chromosomes of pulmonate molluscs // Fretter V., Peake J. (eds.). Pulmonates. Vol.2A. Systematics, Evolution and Ecology. San Francisco: Academic Press. P.172-217.

Pfenninger M., Cordellier M., Streit B., 2006. Comparing the efficacy of morphological and DNA-based taxonomy in the freshwater gastropod genus Radix (Basommatophora, Pulmonata) // BMC Evolutionary Biology. Vol.6. No.100. [http://www.biomedcentral.com/ $1471-2148 / 6 / 100 /]$

Ponder W.F., Waterhouse J. 1997. A new genus and species of Lymnaeidae from the lower Franklin River, south western Tasmania // Journal of Molluscan Studies. Vol.63. P.441-468.

Prozorova L.A. 1998. Annotated list of Beringian frashwater molluscs // Byulleten' Dal'nevostochnogo Malakologicheskogo Obschchestva. Vol.2. P.12-28. 
Prozorova L.A., Foster N. 1997. Specific content of the Beringian freshwater malacofauna // Heldia. Bd.4. P.153-156.

Remigio E.A. 2002. Molecular phylogenetic relationships in the aquatic snail genus Lymnaea, the intermediate host of the causative agent of fascioliasis: insight from broader taxon sampling // Parasitology Research. Vol.88. P.687-696.

Remigio E.A., Blair D. 1997a. Molecular systematics of the freshwater snail family Lymnaeidae (Pulmonata: Basommatophora) utilising mitochondrial ribosomal DNA sequences // Journal of Molluscan Studies. Vol.63. No.2. P.173-185.

Remigio E.A., Blair D. 1997b. Relationships among problematic North American stagnicoline snails (Pulmonata: Lymnaeidae) reinvestigated using nuclear ribosomal DNA internal transcibed spacer sequences // Canadian Journal of Zoology. Vol.75. P.1540-1545.

Rybska E., Pacak A., Szweykowska-Kulinska Z., Lesicki A. 2000. Taxonomy of European Lymnaeidae (Gastropoda: Pulmonata) in studies with the use of molecular biologu techniques. I. Preliminary view on the subgenus Stagnicola Leach, 1830 on the basis of RAPD analysis // Folia Malacologica. Vol.8. P.277-284.

Stadnichenko A.P. 1968. [Galba occulta Jackiewicz, 1959 (Gastropoda, Pulmonata) - new species of the USSR fauna]//Zoologicheskij zhurnal. Vol.47. No.6. P.942944 [in Russian].

Starobogatov Ya.I. 1976. [The system and phylogeny of Lymnaeidae] // Problemy zoologii. Leningrad: Zoologicheskiy Institut AN SSSR. P.79-81 [in Russian].

Starobogatov Ya.I., Budnikova L.L. 1976. [On the fauna of fresh-water gastropod molluscs of the USSR Far North-East] // Presnovodnaya fauna Chukotskogo poluostrova. Trudy Biologo-Pochvennogo Instituta, novaja serija. Vol.36. No.139. P.72-88 [in Russian].

Vinarski M.V. 2003. The systematic position of Lymnaea vulnerata (Küster, 1862) and L. occulta (Jackiewicz, 1959) (Mollusca: Gastropoda: Lymnaeidae)//Zoosystematica Rossica. Vol.12. No.1. P.23-27.

Vinarski M.V. 2006. [On the position of the genus Catascopia Meier-Brook et Bargues, 2002 in the system of the family Lymnaeidae (Gastropoda: Pulmonata)] //
Ekologo-funktsionalni ta faunitichni aspekti doslidzhennya molyuskiv, ikh rol' u bioindikatsii stanu navkolishnyogo seredovischcha. Zhitomir: Zhitomir State University Press. Vol.2. P.49-52 [in Russian].

Vinarsky M.V., Andreev N.I. 2003. [On the taxonomic status of Lymnaea terebra lindholmi (W. Dybowski, 1913) (Gastropoda, Pulmonata, Lymnaeidae)] // Ruthenica. Vol.13. No.2. P.153-156 [in Russian].

Vinarski M.V., Glöer P. 2008. Taxonomical notes on Euro-Siberian freshwater molluscs. 3. Galba occulta Jackiewicz, 1959 is a junior synonym of Limnaea palustris var. terebra Westerlund, 1885 // Mollusca (Dresden). Vol.26. No.2. P.175-185.

Vinarski M., Schniebs K., Glöer P., Hundsdoerfer A. 2011. The taxonomic status and phylogenetic relationships of the genus Aenigmomphiscola Kruglov et Starobogatov, 1981 (Gastropoda: Pulmonata: Lymnaeidae) // Journal of Natural History. Vol.45. No.3334. P.2049-2068.

Vinarski M.V., Schniebs K., Glöer P., Son M.O., Hundsdoerfer A.K. 2012. The steppe relics: taxonomic study on two lymnaeid species endemic to the former USSR (Gastropoda: Pulmonata: Lymnaeidae) // Archiv für Molluskenkunde. Vol.141. No.1. P.67-85.

Walter H.J. 1969. Illustrated biomorphology of the "angulata" lake form of the basommatophoran snail Lymnaea catascopium Say//Malacological Review. Vol.2. P.1-102.

Westerlund C.A. 1885a. Fauna der in der Paläarktischen Region lebenden Binnenconchylien. V. Fam. Succineidae, Auriculidae, Limnaeidae, Cyclostomidae und Hydrocenidae. Lund: Ohlsson. 135+14 S.

Westerlund C.A. 1885b. Land- och Sötvatten-Mollusker insamlade under Vega-Expeditionen af O. Nordqvist och A. Stuxberg // Vega-Expeditionens vetenskapliga iakttagelser. Stockholm: Bejer. Bd.4 S.143-220.

Zhadin V.I. 1952. [Molluscs of the fresh- and brakish waters of USSR] // Opredeliteli po faune SSSR, izdavaemye Zoologicheskim Institutom AN SSSR. Leningrad. No.46. P.1-376 [in Russian].

Responsible editors E.N. Temereva, K.G. Mikhailov 